\title{
STUDIES ON CARBOHYDRATE METABOLISM IN PATIENTS WITH GASTRIC CANCER. DEFECTIVE HEPATIC GLYCOGENESIS; EFFECTS OF ADRENO-CORTICAL EXTRACT ${ }^{1}$
}

\author{
By N. F. YOUNG, ${ }^{2}$ J. C. ABELS, ${ }^{3}$ AND F. HOMBURGER 4 \\ WITH THE TECHNICAL ASSISTANCE OF VERA COLLIER AND JOSEPHINE GREEN
}

(From the Sloan-Kettering Institute for Cancer Research)

(Received for publication June 14, 1948)

\section{INTRODUCTION}

A number of metabolic dysfunctions exist in patients with gastric cancer and may contribute to the malnutrition which often occurs in these patients in spite of an adequate diet (1-3). Thus there has been demonstrated an intractable hypoproteinemia which persists in the presence of body tissue repletion (4). Evidence also has been obtained for alterations in the water and electrolyte metabolism of these patients (5).

The present report deals with experiments designed to study carbohydrate metabolism in patients with gastric cancer. It was found that glucose administered by stomach tube to patients with gastric cancer is not transformed into hepatic glycogen and that this defective hepatic glycogenesis can be corrected by the administration of adrenal cortical extract.

\section{PLAN OF STUDY}

1) Liver glycogen depletion after a 12-hour fast. The concentration of hepatic glycogen was first measured in liver biopsies obtained at laparotomy from 38 patients with gastric cancer after a 12 -hour fast. These findings were controlled by similar studies in 14 patients with benign gastric and duodenal lesions.

2) Hepatic glycogenesis from administered dextrose. In a second experiment, nine patients with gastric cancer were given $250 \mathrm{gm}$. of dextrose in water by stomach tube divided into five doses given at two-hour intervals for ten hours preceding the operation at which time a liver specimen was obtained for determination of glycogen. This procedure was repeated on 15 patients with benign gastric lesions.

3) The effect of adrenal cortical extract on hepatic glycogenesis from administered dextrose. Fourteen pa-

1 This study was aided by grants from the National Institute of Health, National Cancer Institute and the Teagle Fellowship Foundation Fund, New York.

2 Present address: Medical School of Virginia, Richmond, Va.

3 Dr. Abels died on June 13, 1947.

4 Present address: 30 Bennet Street, Boston 11, Mass. tients with gastric cancer were given dextrose as outlined above, and, in addition, received $10-30 \mathrm{ml}$. of Upjohn's aqueous adreno-cortical extract intramuscularly divided into five doses given every two hours during the ten hours preceding operation.

4) The effect of insulin on hepatic glycogenesis from administered dextrose. In six patients with gastric cancer, 5-12 units of insulin were given intramuscularly together with each of five doses of $50 \mathrm{gm}$. of dextrose administered by stomach tube prior to liver biopsy.

5) Studies on regulation of blood sugar in patients with gastric cancer. Intravenous glucose tolerance tests were performed on seven normal subjects and on 13 patients with gastric cancer. In three patients with gastric cancer, this was repeated three times at two-hour intervals. Intravenous insulin tolerance tests were done on five normal subjects and on five patients with gastric cancer.

The effect of a 62-hour fast on blood sugar and urinary nitrogen excretion was studied in three normal subjects and in four patients with gastric cancer. This ,fasting experiment was designed to test the stability of blood sugar concentration under stress as well as to give information on the extent of hepatic gluconeogenesis from endogenous sources.

\section{METHODS}

\section{Preparation of patients and biopsies}

In the ten hours preceding laparotomy, the patients were either fasted completely or received the medication mentioned (vide supra). The amount of residual dextrose solution in all cases was aspirated through the stomach tube at the time of operation, and was found negligible in those cases included in this series. In addition to the medications mentioned uniform pre-operative sedation was employed in all cases. Most of the cases were operated on under pentothal-ether preceded in a few cases by local and spinal anesthesia.

Liver biopsies ${ }^{5}$ were taken immediately upon entering the abdominal cavity and consisted of a piece of hepatic tissue weighing approximately 0.5-1.0 gm. taken from the edge of the right lobe of the liver. This tissue was immediately transferred into a tared dish, weighed and placed in 30 per cent potassium hydroxide for glycogen estimation.

5 The cooperation of Drs. G. T. Pack and Gordon McNeer and the staff of the Gastric Service of Memorial Hospital is gratefully acknowledged. 
II. Determination of liver glycogen; methods of glucose and insulin tolerance tests; other chemical methods

The liver glycogen was determined by the method of Good, Kramer and Somogyi (6). The glucose tolerance tests were performed by the method of Thorn and associates (7). The dietary preparation periods ranged from three to 62 days. Capillary blood was taken for blood sugar determinations by the method of Somogyi, ShafferHartmann (8) after protein precipitation according to Folin-Wu as modified by Van Slyke and Hawkins (9).

One-tenth of a U.S.P. unit of crystalline insulin per $\mathrm{kg}$. of body weight was used in the intravenous tolerance tests (10).

In the balance studies, nitrogen was determined by a Kjeldahl method in diets and urine.

\section{RESULTS}

(1) Degree of liver glycogen depletion after a 12hour fast

The values obtained for liver glycogen in the fasting patients were identical in the control and in the cancer group (Figure 1, Tables I and Ia).

(2) Hepatic glycogenesis from administered dextrose

The concentration of hepatic glycogen in patients with benign gastric and duodenal lesions following
TABLE I

Benign gastric lesions-no treatment

\begin{tabular}{c|c|c|c|l}
\hline $\begin{array}{c}\text { Liver } \\
\text { glycogen }\end{array}$ & $\begin{array}{c}\text { Hospital } \\
\text { Case No. }\end{array}$ & Age & Sex & Diagnosis \\
\cline { 1 - 2 } & & & & \\
0.4 & 56612 & 35 & $\mathrm{~m}$ & jejunal ulcer \\
0.4 & 77727 & 40 & $\mathrm{~m}$ & gastric ulcer \\
0.5 & 75594 & 52 & $\mathrm{f}$ & gastric ulcer \\
0.9 & 79352 & 57 & $\mathrm{~m}$ & gastric ulcer \\
1.3 & 65722 & 58 & $\mathrm{~m}$ & gastritis \\
1.4 & 64874 & 63 & $\mathrm{f}$ & gastritis \\
1.6 & 76358 & 69 & $\mathrm{~m}$ & duodenal ulcer \\
1.8 & 71505 & 51 & $\mathrm{~m}$ & duodenal ulcer \\
2.8 & 64784 & 57 & $\mathrm{f}$ & peptic ulcers \\
2.8 & 76509 & 50 & $\mathrm{~m}$ & gastric ulcer \\
3.1 & 78661 & 18 & $\mathrm{~m}$ & duodenal cyst \\
3.6 & 69269 & 55 & $\mathrm{~m}$ & gastric ulcer \\
3.6 & 64791 & 60 & $\mathrm{~m}$ & gastric ulcer \\
4.2 & 79589 & 40 & $\mathrm{~m}$ & duodenal ulcer \\
\hline
\end{tabular}

2.0 average value.

the administration of $250 \mathrm{gm}$. of dextrose ranged from $4.6 \mathrm{gm} . / 100 \mathrm{gm}$. of tissue to $9.7 \mathrm{gm} . / 100 \mathrm{gm}$. of tissue and averaged $7.6 \mathrm{gm} . / 100 \mathrm{gm}$. of tissue (Figure 1, Tables II and IIa).

In contrast to this, the concentration of hepatic glycogen in patients with gastric cancer under the same conditions ranged from $1.1 \mathrm{gm} . / 100 \mathrm{gm}$. of tissue to $6.0 \mathrm{gm} . / 100 \mathrm{gm}$. of tissue (Figure 1).

\section{O BENIGN GASTRIC LESIONS - GASTRIC CANCER}

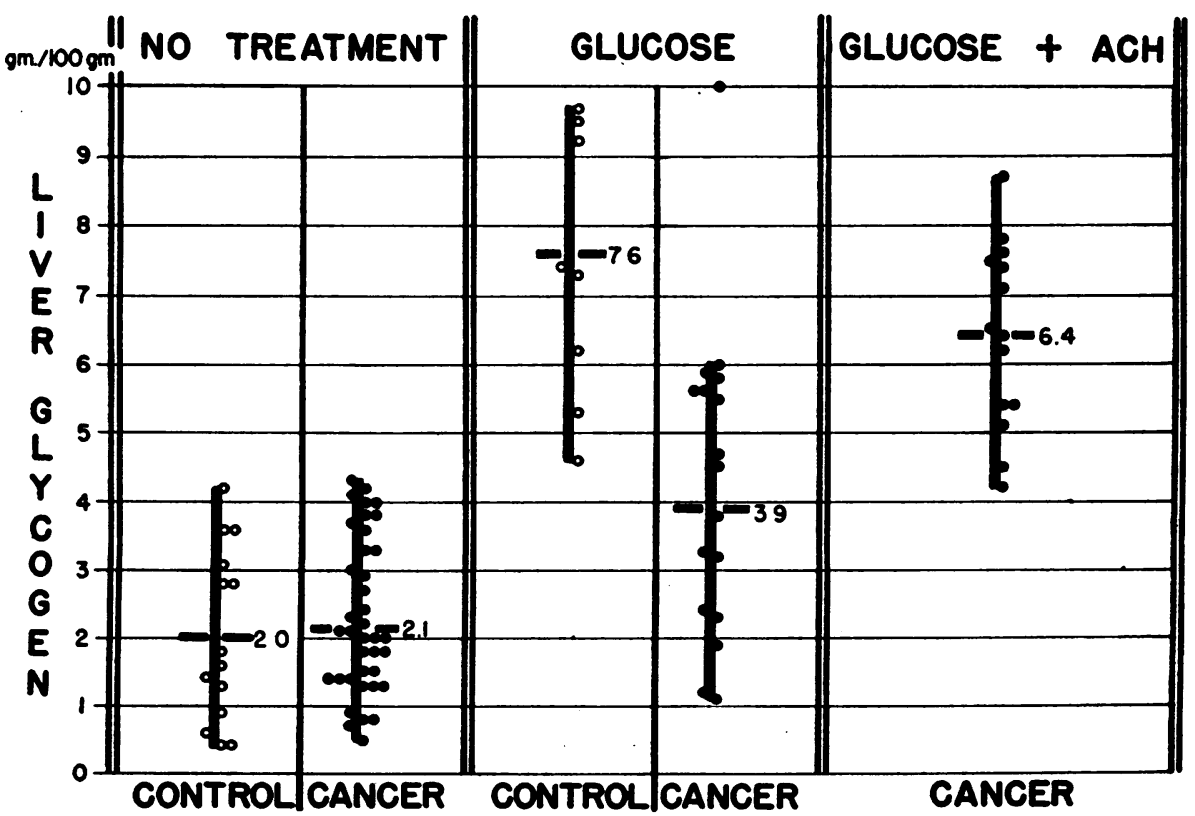

Fig. 1. Concentration of Liver Glycogen in Patients with Gastric Cancer and with Benign Gastric Lesions 
TABLE Ia

Gastric cancer-no treatment

\begin{tabular}{|c|c|c|c|c|c|c|}
\hline \multirow{2}{*}{$\begin{array}{c}\text { Liver } \\
\text { glycogen }\end{array}$} & \multirow{2}{*}{$\begin{array}{l}\text { Hospital } \\
\text { Case No. }\end{array}$} & \multirow{2}{*}{ Age } & \multirow{2}{*}{ Sex } & \multirow{2}{*}{ Tumor* } & \multicolumn{2}{|c|}{ Metastases† } \\
\hline & & & & & Liver & Elsewhere \\
\hline $\begin{array}{c}\mathrm{gm} .100 \mathrm{gm} . \\
0.5 \\
0.7 \\
0.8 \\
0.8 \\
0.9 \\
1.3 \\
1.3 \\
1.3 \\
1.4 \\
1.4 \\
1.4 \\
1.5 \\
1.5 \\
1.8 \\
1.8 \\
1.8 \\
2.0 \\
2.0 \\
2.0 \\
2.1 \\
2.1 \\
2.2 \\
2.3 \\
2.4 \\
2.7 \\
2.9 \\
3.0 \\
3.3 \\
3.3 \\
3.6 \\
3.7 \\
3.8 \\
3.8 \\
4.0 \\
4.0 \\
4.1 \\
4.2 \\
4.3 \\
\end{array}$ & $\begin{array}{l}66224 \\
77377 \\
70734 \\
68786 \\
77532 \\
64441 \\
75766 \\
64910 \\
68971 \\
77529 \\
64216 \\
71497 \\
65824 \\
64409 \\
66457 \\
64331 \\
64866 \\
64744 \\
65604 \\
68997 \\
64518 \\
79195 \\
70528 \\
64927 \\
65198 \\
66545 \\
64715 \\
70748 \\
64821 \\
64391 \\
68958 \\
77655 \\
63706 \\
69689 \\
65407 \\
70995 \\
65083 \\
64618\end{array}$ & $\begin{array}{l}53 \\
41 \\
53 \\
46 \\
45 \\
60 \\
64 \\
58 \\
63 \\
35 \\
62 \\
50 \\
57 \\
75 \\
37 \\
59 \\
66 \\
76 \\
65 \\
60 \\
65 \\
58 \\
50 \\
70 \\
54 \\
54 \\
59 \\
62 \\
63 \\
46 \\
62 \\
56 \\
48 \\
43 \\
56 \\
49 \\
46 \\
48\end{array}$ & $\begin{array}{l}\mathrm{m} \\
\mathbf{f} \\
\mathbf{f} \\
\mathrm{m} \\
\mathrm{m} \\
\mathrm{m} \\
\mathrm{m} \\
\mathrm{m} \\
\mathrm{m} \\
\mathrm{f} \\
\mathrm{m} \\
\mathrm{m} \\
\mathrm{m} \\
\mathrm{f} \\
\mathrm{m} \\
\mathrm{m} \\
\mathrm{m} \\
\mathrm{f} \\
\mathrm{m} \\
\mathrm{f} \\
\mathrm{m} \\
\mathrm{m} \\
\mathrm{f} \\
\mathrm{m} \\
\mathrm{m} \\
\mathrm{m} \\
\mathrm{f} \\
\mathrm{f} \\
\mathrm{m} \\
\mathrm{m} \\
\mathrm{m} \\
\mathrm{m} \\
\mathrm{f} \\
\mathrm{m} \\
\mathrm{f} \\
\mathrm{m} \\
\mathrm{m} \\
\mathrm{f}\end{array}$ & $\begin{array}{l}\mathbf{0} \\
\mathbf{0} \\
\mathbf{0} \\
\mathbf{0} \\
\mathbf{0} \\
\mathbf{i} \\
\mathbf{o} \\
\mathbf{0} \\
\mathbf{i} \\
\mathbf{0} \\
\mathbf{i} \\
\mathbf{i} \\
\mathbf{i} \\
\mathbf{0} \\
\mathbf{i} \\
\mathbf{i} \\
\mathbf{o} \\
\mathbf{0} \\
\mathbf{0} \\
\mathbf{i} \\
\mathbf{i} \\
\mathbf{i} \\
\mathbf{i} \\
\mathbf{i} \\
\mathbf{i} \\
\mathbf{i} \\
\mathbf{o} \\
\mathbf{i} \\
\mathbf{o} \\
\mathbf{0} \\
\mathbf{i} \\
\mathbf{i} \\
\mathbf{i} \\
\mathbf{i} \\
\mathbf{o} \\
\mathbf{i} \\
\mathbf{i} \\
\mathbf{i}\end{array}$ & 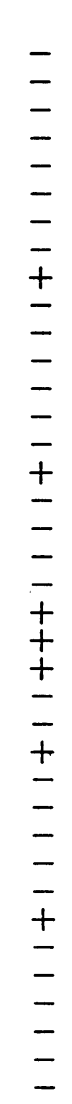 & $\begin{array}{c}+\dot{t}+ \\
\bar{t} \\
+\dot{+}+ \\
\underline{+}+ \\
+++ \\
\overline{+} \\
+++ \\
+++ \\
+ \\
+++ \\
+ \\
+\end{array}$ \\
\hline
\end{tabular}

2.1 average value.

* Tumor operable $=0$; tumor inoperable $=\mathrm{i}$.

† Single or occasional metastasis $=+$; massive, widespread metastases $=+++$.

TABLE II

Benign gastric lesions-glucose

\begin{tabular}{|c|c|c|c|c|}
\hline $\begin{array}{c}\text { Liver } \\
\text { glycogen }\end{array}$ & Number & Age & Sex & Diagnosis \\
\hline $\begin{array}{c}\mathrm{gm.} / 100 \mathrm{gm} . \\
4.6 \\
5.3 \\
6.2 \\
7.3 \\
7.4 \\
9.1 \\
9.2 \\
9.5 \\
9.7\end{array}$ & \begin{tabular}{|l}
71428 \\
69499 \\
65622 \\
\\
65821 \\
79862 \\
63450 \\
68194 \\
75119
\end{tabular} & $\begin{array}{l}54 \\
55 \\
59 \\
63 \\
59 \\
49 \\
58 \\
30\end{array}$ & $\begin{array}{l}\mathbf{m} \\
\mathbf{m} \\
\mathbf{m} \\
\mathbf{f} \\
\mathbf{f} \\
\mathbf{f} \\
\mathbf{m} \\
\mathbf{f}\end{array}$ & $\begin{array}{l}\text { duodenal ulcer } \\
\text { gastric ulcer } \\
\text { duodenal ulcer } \\
\text { gastric ulcer } \\
\text { abdominal aorta aneurysm } \\
\text { duodenal ulcer } \\
\text { gastric ulcer } \\
\text { gastric polyposis, benign } \\
\text { pancreatic cyst }\end{array}$ \\
\hline
\end{tabular}

7.6 average value.
TABLE IIa

Gastric Cancer-glucose

\begin{tabular}{|c|c|c|c|c|c|c|}
\hline \multirow{2}{*}{$\begin{array}{c}\text { Liver } \\
\text { glycogen }\end{array}$} & \multirow{2}{*}{$\begin{array}{l}\text { Hospital } \\
\text { Case No. }\end{array}$} & \multirow{2}{*}{ Age } & \multirow{2}{*}{ Sex } & \multirow{2}{*}{ Tumort } & \multicolumn{2}{|c|}{ Metastases } \\
\hline & & & & & Liver & Elsewhere \\
\hline $\begin{array}{c}\mathrm{gm} . / 100 \mathrm{gm} . \\
1.1 \\
1.2 \\
1.9 \\
2.3 \\
2.4 \\
3.2 \\
3.3 \\
3.8 \\
4.5 \\
4.7 \\
5.5 \\
5.6 \\
5.8 \\
5.9 \\
6.0\end{array}$ & $\begin{array}{l}70702^{*} \\
71443 \\
70753 \\
68530 \\
79930 \\
81158 \\
81115 \\
73025 \\
65586 \\
73406 \\
71429 \\
71017 \\
81560 \\
65834 \\
79157\end{array}$ & $\begin{array}{l}42 \\
64 \\
69 \\
65 \\
71 \\
69 \\
58 \\
64 \\
62 \\
70 \\
64 \\
53 \\
60 \\
53 \\
58\end{array}$ & $\begin{array}{l}\mathrm{m} \\
\mathrm{m} \\
\mathrm{m} \\
\mathrm{m} \\
\mathrm{m} \\
\mathrm{m} \\
\mathrm{f} \\
\mathrm{f} \\
\mathrm{m} \\
\mathrm{m} \\
\mathrm{m} \\
\mathrm{m} \\
\mathrm{m} \\
\mathrm{m} \\
\mathrm{m}\end{array}$ & $\begin{array}{l}0 \\
0 \\
\mathbf{i} \\
\mathbf{i} \\
\mathbf{i} \\
\mathrm{i} \\
\mathrm{i} \\
\mathbf{0} \\
\mathbf{i} \\
\mathrm{i} \\
\mathbf{0} \\
\mathbf{i} \\
\mathbf{i} \\
\mathbf{i} \\
\mathbf{i}\end{array}$ & $\begin{array}{l}- \\
\overline{+} \\
+ \\
- \\
\overline{+} \\
\overline{+} \\
+ \\
- \\
- \\
\overline{+} \\
+++\end{array}$ & $\begin{array}{c}\bar{t} \\
+ \\
+t \\
+ \\
+\end{array}$ \\
\hline
\end{tabular}

3.9 average value.

* Lymphosarcoma of stomach.

$\uparrow$ Tumor operable $=0$; tumor inoperable $=i$.

(There was one exception with a value of $10 \mathrm{gm} . /$ $100 \mathrm{gm}$. of tissue in a case of cancer of the esophageal end of the stomach in a woman of 28 , the youngest in the entire series.) Excluding this one extreme value the average was $3.9 \mathrm{gm} . / 100$ gm. of tissue.

(3) The effect of adrenal cortical extract. on hepatic glycogenesis from administered glucose

In 14 patients with gastric cancer who had received adrenal cortical extract together with dextrose, the hepatic concentration of glycogen ranged from $4.2 \mathrm{gm}$. $/ 100 \mathrm{gm}$. of tissue to $8.7 \mathrm{gm} . / 100 \mathrm{gm}$. of tissue, with an average value of $6.4 \mathrm{gm} . / 100 \mathrm{gm}$. of tissue (Figure 1 and Table III).

\section{(4) The effect of insulin on hepatic glycogenesis from administered dextrose}

The administration of insulin together with dextrose in six patients with gastric cancer resulted in an insignificant depression of their liver glycogen to an average value of $3.6 \mathrm{gm} . / 100 \mathrm{gm}$. of tissue (Figure 2).

(5) Studies on the regulation of blood sugar in patients with gastric cancer

There were minor differences between the glucose tolerance curves in patients with gastric can- 
TABLE III

Gastric cancer-glucose $+\mathrm{ACH}$

\begin{tabular}{|c|c|c|c|c|c|c|c|}
\hline \multirow{2}{*}{$\begin{array}{c}\text { Liver } \\
\text { glycogen }\end{array}$} & \multirow{2}{*}{$\mid \begin{array}{l}\text { Hospital } \\
\text { Case No. }\end{array}$} & \multirow{2}{*}{ Age } & \multirow{2}{*}{ Sex } & \multirow{2}{*}{$\underset{\text { amount }}{\mathrm{ACH}}$} & \multirow{2}{*}{ Tumort } & \multicolumn{2}{|c|}{ Metastases } \\
\hline & & & & & & Liver & $\begin{array}{c}\text { Else- } \\
\text { where }\end{array}$ \\
\hline $\begin{array}{c}\mathrm{gm.} / 100 \mathrm{gm} . \\
4.2 \\
4.5 \\
5.1 \\
5.4 \\
5.4 \\
6.2 \\
6.4 \\
6.5 \\
7.1 \\
7.4 \\
7.5 \\
7.6 \\
7.8 \\
8.7\end{array}$ & \begin{tabular}{|l|}
73016 \\
73033 \\
72419 \\
72404 \\
72985 \\
73548 \\
72285 \\
72615 \\
72778 \\
73396 \\
72227 \\
73457 \\
72497 \\
72938
\end{tabular} & $\begin{array}{l}49 \\
65 \\
48 \\
66 \\
64 \\
59 \\
63 \\
57 \\
69 \\
49 \\
37 \\
70 \\
61 \\
68\end{array}$ & $\begin{array}{c}\mathbf{m} \\
\mathbf{m} \\
\mathbf{f} \\
\mathbf{m} \\
\mathbf{m} \\
\mathbf{m} \\
\mathbf{m} \\
\mathbf{f} \\
\mathbf{f} \\
\mathbf{m} \\
\mathbf{f} \\
\mathbf{m} \\
\mathbf{f} \\
\mathbf{f}\end{array}$ & $\begin{array}{l}c c . \\
20 \\
30 \\
10 \\
10 \\
30 \\
30 \\
10 \\
20 \\
20 \\
30 \\
20 \\
30 \\
20 \\
20\end{array}$ & $\begin{array}{l}\mathbf{0} \\
\mathbf{0} \\
\mathbf{i} \\
\mathbf{o} \\
\mathbf{i} \\
\mathbf{0} \\
\mathbf{0} \\
\mathbf{0} \\
\mathbf{0} \\
\mathbf{0} \\
\mathbf{0} \\
\mathbf{0} \\
\mathbf{i} \\
\mathbf{i}\end{array}$ & $\begin{array}{l}\overline{-} \\
\overline{-} \\
\overline{-} \\
\overline{-} \\
\overline{-} \\
\overline{-} \\
\overline{-} \\
\overline{-} \\
-\end{array}$ & $\begin{array}{c}\bar{t} \\
++t \\
\bar{t} \\
+ \\
\pm \\
\bar{t} \\
\pm \\
\bar{t} \\
+ \\
+t+\end{array}$ \\
\hline
\end{tabular}

6.4 average value.

* Epidermoid carcinoma of esophagus.

$\dagger$ Tumor operable $=0$; tumor inoperable $=i$.

cer and those of patients free of cancer. Thus the average value of the peak of the tolerance curve was $22 \mathrm{mg}$. per cent higher in the patients with gastric cancer. The slope of the disappearance curve was similar in both groups. The fasting blood sugar levels of patients with gastric cancer were on the average $12 \mathrm{mg}$. per cent higher than in the controls.

The response to a test dose of insulin was the same in a group of four patients with gastric cancer as in a control group of five normal subjects (Figure 3).

The response to repeated intravenous glucose tolerance tests (every two hours) was essentially

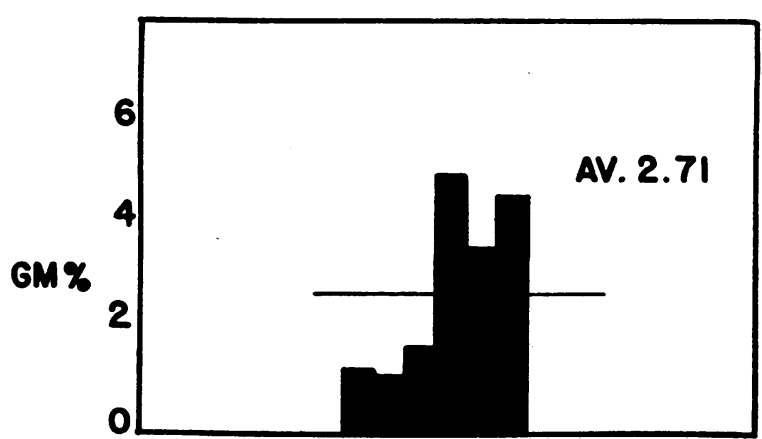

Fig. 2. The Concentrations of Glycogen in the Livers of Patients with Gastro-Instestinal Cancer after Feeding of 250 GM. Glucose and Administration OF 30-60 U OF INSULIN
EFFECT OF INSULIN $\left(0.1 \mathrm{U} / \mathrm{kg}_{0} B W\right)$ ON BLOOD SUGAR

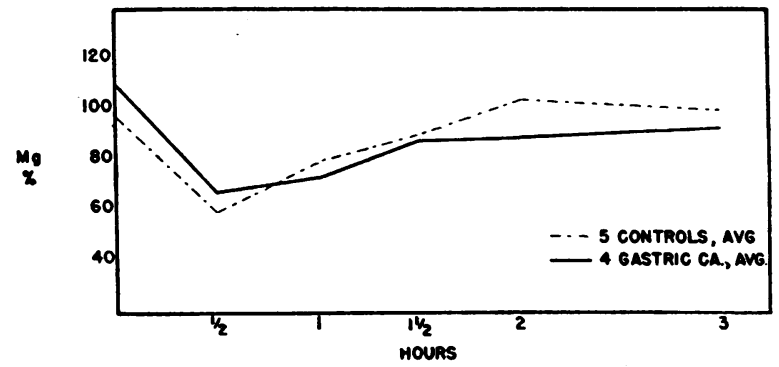

FIG. 3

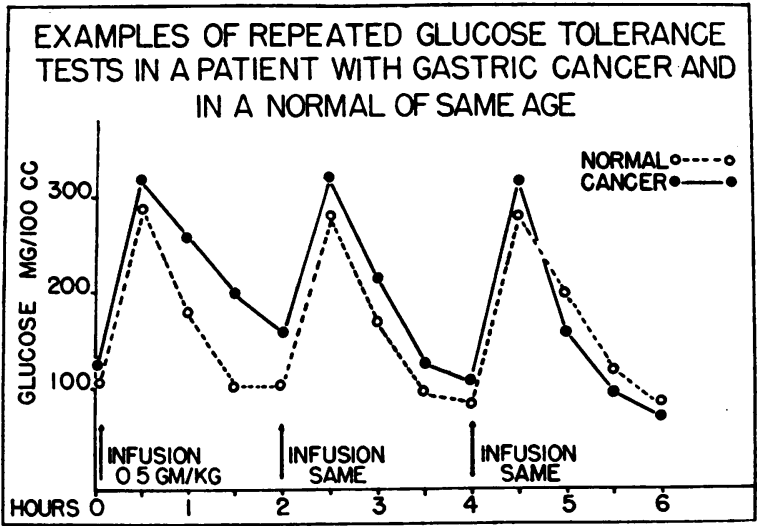

FIG. 4

FASTING EXPERIMENTS

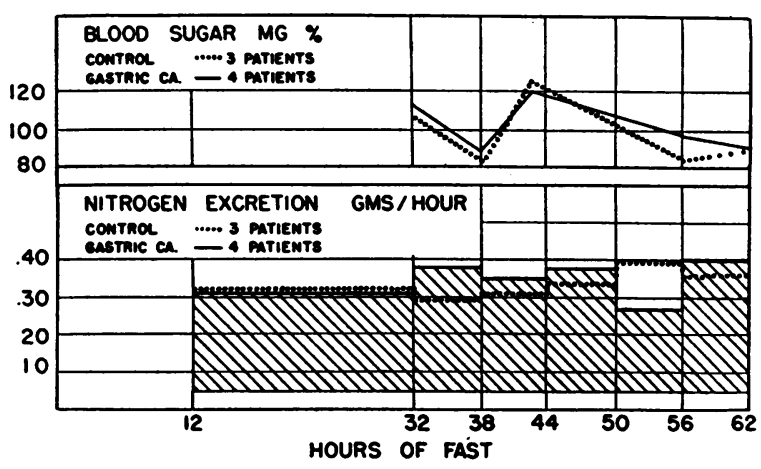

Fig. 5. Nitrogen Excretion in Controls and Gastric Cancer Patients

the same in patients with gastric cancer as in normals (Figure 4).

The blood sugar concentration in patients with gastric cancer during a 62-hour fast closely resembled that found in patients without gastric cancer under similar conditions. The nitrogen excretion in both groups was the same during the fast (Figure 5). 


\section{DISCUSSION}

These results demonstrate that patients with gastric cancer fail to transform glucose given by stomach tube into hepatic glycogen at a normal rate. The administration of adrenal cortical extract corrects this abnormality. However, the defect is not similar to that prevailing in adrenalectomized animals or in patients with Addison's disease where blood sugar and hepatic glycogen as well as the urinary excretion of nitrogen are lowered by fasting $(11,12)$. Furthermore, such subjects exhibit marked insulin sensitivity.

The gluconeogenesis from endogenous sources in patients with gastric cancer proceeds normally as manifested by normal fasting concentrations of liver glycogen and by normal behavior of blood sugar and nitrogen excretion during a 62-hour fast (Figure 3). Furthermore, these patients responded normally to the separate intravenous injection of dextrose and insulin as well as to the repeated injection of test doses of dextrose at two-hour intervals. The slight differences in the fasting blood sugar levels and in the peak blood sugar levels during the glucose tolerance tests were satisfactorily explained by the age difference that existed between the control (young) and the cancer group (old )(13). There were no significant differences when individuals of equal age only were compared.

One is thus faced with a dysfunction of carbohydrate metabolism which, while corrected by adrenal hormones, is unlike the disturbance found in adrenalectomized animals. It would appear possible that glucose was poorly absorbed from the gastro-intestinal tract in patients with gastric cancer. However, a similar situation where intestinal malabsorption is ruled out prevails following the intraperitoneal administration of dextrose (14) in mice bearing Sarcoma 180.

The mechanisms of this defective hepatic glycogenesis from administered glucose are as yet poorly understood and call for further studies.

The abnormality is independent of the existence of tumor metastases in the liver or elsewhere and there is no relationship between the size of the total tumor mass and the severity of the disturbance.

The prompt amelioration of this defect by the simultaneous pre-operative administration of glu- cose and adrenal cortical extract would seem to indicate the use of these measures to prepare patients for major abdominal operations, especially for surgery in gastric cancer.

\section{SUMMARY}

1. Patients with gastric cancer fail to transform into hepatic glycogen dextrose that has been given by stomach tube.

2. This metabolic defect is corrected by the injection of adrenal cortical extract.

3. Insulin has no effect on the disturbed hepatic glycogenesis from administered dextrose.

4. This hepatic glycogenesis from endogenous sources in a 12-hour fast is normal and no evidence of disturbed glycogenesis was obtained in a 62hour fast. The regulation of the peripheral blood sugar and the sensitivity to insulin are normal in patients with gastric cancer.

\section{BIBLIOGRAPHY}

1. Abels, J. C., Ariel, I. M., Rekers, P. F., Pack, G. T., and Rhoads, C. P., Metabolic abnormalities of patients with cancer of the gastro-intestinal tract; review of recent studies. Arch. Surg., 1943, 46, 844.

2. Abels, J. C., Homburger, F., Young, N. F., Pack, G. T., and Rhoads, C. P., Metabolic studies in cancer. Conference on Metabolic Aspects of Convalescence. 13th Meeting, June 1946, pp. 89-111.

3. Rhoads, C. P., Studies of patients with gastric cancer. J. Nat. Cancer Inst., 1947, 7, 333.

4. Homburger, F., and Young, N. F., Hypoproteinemia in patients with gastric cancer; its persistence in spite of tissue repletion. Blood, in press.

5. Homburger, F., Young, N. F., and Abels, J. C., Studies on electrolyte exchanges in patients with gastric cancer. Proc. Am. Federation Clin. Research, 1947, 3, 55.

6. Good, C. A., Kramer, H., and Somogyi, M., Determination of glycogen. J. Biol. Chem., 1933, 100, 485.

7. Thorn, G. W., Koepf, G. F., Lewis, R. A., and Olsen, E. F., Carbohydrate metabolism in Addison's disease. J. Clin. Invest., 1940, 19, 813.

8. Shaffer, P. A., and Somogyi, M., Copper-iodometric reagents for sugar determination. J. Biol. Chem., 1933, 100, 695.

9. Van Slyke, D. D., and Hawkins, J. A., A gasometric method for the determination of reducing sugar and its application to the analysis of blood and urine. J. Biol. Chem., 1928, 79, 739. 
10. Rosenbaum, J. D., De Kruif, H., and Lavietes, P. H., Effect of insulin on glucose tolerance of normal man. J. Clin. Invest., 1944, 23, 45.

11. Long, C. N. H., Katzin, B., and Fry, E. G., Adrenal cortex and carbohydrate metabolism. Endocrinology, 1940, 26, 309.

12. Long, C. N. H., A discussion of the mechanisms of action of adrenal cortical hormones on carbo- hydrate and protein metabolism. Endocrinology, 1942, 30, 870.

13. Kohl, H., and Dahmann-Donn, H., Blutzuckerbelastungen in verschiedenen Lebensaltern. Ztschr. f. Altersforschung, 1940, 2, 310 .

14. Young, N. F., Kensler, C. J., Seki, L., and Homburger, F., Deposition of liver glycogen in normal mice and in mice bearing Sarcoma 180. Proc. Soc. Exp. Biol. \& Med., 1947, 66, 322. 